\title{
DIREITO, MANIFESTAÇÃO E VIOLÊNCIA: LEITURAS DOS PROTESTOS DE JUNHO DE 2013
}

\section{LAW, MANIFESTATION AND VIOLENCE: READINGS OF THE BRAZILIAN PROTESTS OF JUNE 2013}

${ }^{1}$ José Antonio Rego Magalhães

\section{RESUMO}

Neste artigo, começaremos por apresentar uma certa crítica da violência, introduzida por Walter Benjamin em Para uma Crítica da Violência e desenvolvida/desconstruida por Jacques Derrida em Força de Lei. Apresentaremos o arcabouço conceitual dessa crítica, em conceitos como os de violência que instaura e violência que mantém o direito, violência do direito e violência anômica, puro meio, manifestação, legibilidade e evento. A partir desses conceitos, entraremos então em uma discussão teórica promovida por alguns intelectuais e acadêmicos brasileiros, em especial na compilação de artigos intitulada Cidades Rebeldes: Passe livre e as manifestações que tomaram as ruas do Brasil. Algumas das questões abordadas serão: o que significa interpretar uma manifestação; qual o papel da teoria diante desses fenômenos; como pode uma violência vinda das ruas transformar o direito; como diferenciar uma violência legítima ou ilegítima; etc.

Palavras-chave: Direito, Violência, Manifestações, Junho de 2013

\begin{abstract}
In this paper, we will begin by presenting a certain critique of violence, introduced by Walter Benjamin in Critique of Violence and developed/deconstructed by Jacques Derrida in Force of Law. We will present the concepts involved in this criticism, such as those of violence that founds law and violence that maintains law, legal violence and anomic violence, pure means, manifestation, readability and event. Departing from those concepts, we will then go into a theoretical discussion promoted by some Brazilian intellectuals and academics, especially in the compilation of articles titled Rebel Cities: Passe livre and the protests that took over the streets of Brazil. Some of the questions dealt with are: what it means to interpret a manifestation; what the role of theory is in the face of those phenomena; how a violence from the streets can transform law; how to differentiate between legitimate and illegitimate violence; etc.
\end{abstract}

Keywords/Palabras-claves/Mots-clés: Law, Violence, Brazil, June of 2013

\footnotetext{
${ }^{1}$ Professor na Universidade Federal do Rio de Janeiro (UFRJ), Rio de Janeiro (Brasil). Doutorando em Direito pela Pontifícia Universidade Católica do Rio de Janeiro (PUC/RJ), Rio de Janeiro (Brasil). E-mail: jamagalhaes22@gmail.com
} 
Atenção

Tudo é perigoso

- Caetano Veloso

\section{Introdução}

Neste artigo, partirei de um certo pensamento do direito e da violência para discutir o tema das manifestações de junho de 2013, em especial no que tange às suas relações com a esfera do direito. Esse pensamento se constrói (e desconstrói) em dois momentos - no ensaio "Zur Kritik der Gewalt” ("Para uma Crítica da Violência”), de Walter Benjamin, publicado em 1921, e na conferência Force de Loi: Le "Fondement Mystique de L'autorité" (Força de Lei: o “Fundamento Místico da Autoridade”), proferida em outubro de 1989 por Jacques Derrida, em especial a sua segunda parte, intitulada “Prénom de Benjamin” (Prenome de Benjamin).

Benjamin, há quase um século, já fazia uma crítica que se afina com a "crise da democracia representativa" frequentemente diagnosticada hoje. Segundo ele, a "lógica do compromisso" (no sentido de negociação de interesses) adotada pelos parlamentos - qualquer semelhança com o PMDBismo é mera coincidência - desconecta essas instituições das forças que as fundaram, escondendo e recalcando a violência presente em suas atividades. A lógica do compromisso, porém, é violenta, pois se assemelha à chantagem (Benjamin, 2011). Não seria esse apagamento da violência originária do parlamentarismo que leva ao afastamento verificado hoje entre as necessidades do povo e as ações dos seus representantes? O compromisso em questão acaba sendo não entre os interesses de diferentes parcelas representadas da população, mas entre os interesses de diferentes oligarquias políticas e econômicas, cujo principal propósito é manter a correlação de forças da qual se aproveitam.

Nesse quadro, a reaparição, nas ruas, de tensões voltadas a refundar, destruir ou transformar o direito, talvez seja a resposta a essa frustração, na medida em que impõe o restauro da relação fundamental entre direito e violência, entre o direito e a soberania que, na democracia, seria popular. Por isso, uma compreensão articulada das relações entre direito e violência talvez seja mais necessária hoje do que o era há muito tempo.

O que diferencia o direito, como violência legítima (e portanto "não-violenta"), das violências que rejeitamos? Como um Estado, fundado sempre por uma violência, pode expiar 
essa violência da sua estrutura? Que tipo de legitimidade, se alguma, podemos atribuir a uma violência que se volta contra o Estado, contra o direito? Como uma violência externa ao direito pode, de alguma forma, transformá-lo? Como podemos atribuir sentido à violência que surge nas ruas? Essa atribuição de sentido não é, em si mesma, uma violência? Como o direito reage a tais violências? O direito pode fazer-se menos violento? A violência que transforma o direito pode partir do próprio direito? Como a demanda por um direito específico se insere nessa dinâmica? A violência das ruas clama por direitos, ou contra o direito? São algumas das questões que de alguma forma se relacionam ao nosso tema.

O Movimento Passe Livre, exigindo um certo direito à cidade, foi o estopim das manifestações que chacoalharam o país em 2013, mas o que se produziu a partir daí esteve longe de ser homogêneo. De "cidadãos de bem" cantando o hino nacional a black blocs confrontando fisicamente o Estado, passando por militantes de partidos e meros "turistas", as manifestações da era do facebook, sem organização centralizada, tornaram-se praticamente impossíveis de interpretar. Não obstante, as tentativas de interpretação foram muitas, e de todos os matizes, ainda que, na maioria das vezes, baseadas mais no "wishful thinking" de um dos lados do que em qualquer epistemologia.

Não é evidente que seja útil teorizar sobre as manifestações. Tampouco é evidente que essa teorização deva se dar em termos epistemológicos ou interpretativos, ou seja, em termos de produzir um certo conhecimento sobre o seu verdadeiro significado. A questão é anterior, no sentido de que a própria produção de conhecimento, longe de ser imparcial e não-violenta, está baseada em uma certa ordem das coisas, e por isso mesmo não deve ser tomada por garantida quando se discute, justamente, a subversão ou transformação da ordem.

Uma crítica interessante da violência, como a que procuraremos explorar no presente artigo, deve antes de mais nada questionar as relações entre diferentes ordens, entre diferentes direitos, relações de fundação, conservação, subversão e transformação, e mesmo de simples deposição, como veremos em breve. Essas relações não podem depender de epistemologias pressupostas, pois é a própria epistemologia que dependerá delas.

Começaremos este artigo apresentando a crítica da violência de Walter Benjamin e a desconstrução que, a partir dela, opera Derrida. Os conceitos de violência que instaura e que conserva o direito, "puro meio", legibilidade e evento, apresentados então, serão utilizados a seguir para discutir com alguns analistas cujas interpretações das "jornadas de junho" foram reunidas no livro "Cidades Rebeldes”. É a partir dessas análises, e portanto de forma teórica, mais do que empírica, que discutiremos o tema das manifestações e da sua relação com o direito. 
Se em alguns momentos os intelectuais e acadêmicos sob análise - de modo geral de esquerda e abertamente simpáticos às manifestações - apressam-se em atribuir fins aos fenômenos que observam, sem problematizar essa relação de conhecimento como poder (o que será objeto de crítica ao longo do artigo), em outros fornecem descrições e teorizações muito interessantes, que podem contribuir - aqui através de um paralelo traçado com a crítica da violência de Benjamin e Derrida - para uma compreensão da dinâmica entre fundação e deposição, direito e anomia, violência e não-violência, continuidade e ruptura, que deve ajudarnos a manter a capacidade crítica necessária em tempos em que tudo parece estar em jogo.

\section{Crítica da violência}

Benjamin (2011) se propõe, em seu ensaio, a desenvolver uma crítica da violência. A palavra "crítica", nesse caso, não se refere a um argumento voltado a rejeitar a violência de modo geral, mas ao estabelecimento de critérios que permitam julgar a violência, isto é, de algum modo separar a violência que podemos aceitar (legítima? justa?) daquela que devemos rejeitar (ilegítima? injusta?).

A violência, para Benjamin (2011), só pode ser julgada a partir das suas relações com a esfera do direito e da justiça. Como o par fundamental na esfera do direito, para ele, é o par meios/fins (o direito se ocupa dos meios justificados ou proibidos para atingir fins justos ou injustos), é desse par que a crítica da violência se ocupará.

É essencial notar que, quando fala de violência, Benjamin usa a palavra Gewalt, que em alemão significa também "autoridade" ou "poder", no sentido de "poder constituinte", por exemplo. A equivocidade dessa palavra nos acompanhará por toda a discussão, mesmo para além de Benjamin, e é justamente a tensão entre violação e instauração estabelecida por esse duplo sentido que nos manterá ocupados.

Em seu ensaio, Benjamin (2011, p.126) se debruça sobre diversas "relações de direito" que geravam polêmica à época (República de Weimar) e que, de uma forma ou de outra, põem em questão a relação entre direito e violência. Ele aborda o direito à legítima defesa, a figura do grande criminoso, o direito a greve e a greve geral revolucionária, o direito de guerra, o serviço militar obrigatório, a pena de morte, a polícia, o parlamentarismo, etc. A partir dessas análises, emergem distinções importantes, a partir da relação meios/fins.

Em primeiro lugar, Benjamin (2011) distingue a violência que instaura e a violência que mantém o direito, ambas relacionadas como meio a um fim. Mais adiante, questiona o pressuposto que essas violências do direito se voltem a qualquer fim além da imposição 
continuada delas mesmas. A partir daí, traça uma nova distinção entre a violência do direito (que chama "mítica"), voltada apenas à continuidade da sua própria aplicação, e a violência anômica (que chama "divina"), voltada a depor o direito.

A proposta de Benjamin é que o ciclo vicioso da violência "mítica" do direito deve ser interrompido a todo custo. Segundo Agamben (2004, p.84), “o objetivo do ensaio é garantir a possibilidade de uma violência absolutamente 'fora' e 'além' do direito e que, como tal, poderia romper a dialética entre a violência que funda o direito e a violência que o conserva". Trata-se da violência "divina".

Essa violência anômica, voltada a depor o direito, é identificada por Benjamin, no que toca ao par meios/fins, ao "puro meio", isto é, uma violência que não se relaciona como meio a certos fins, mas que apenas manifesta a si mesma. Na esfera privada, Benjamin relaciona a ideia de "puro meio" ao diálogo livre e aberto entre pessoas; na esfera pública, a relaciona ao conceito de "greve geral proletária", de Georges Sorel.

\section{1. "Puro meio"}

Sorel (1972) distingue em seu livro Réflexions sur la Violence, a greve geral voltada a fundar um novo Estado (greve geral política), e aquela voltada a destruir o Estado (greve geral proletária). Parece haver aqui um paralelismo com a distinção entre a violência que instaura o direito e aquela que o depõe.

A figura do direito de greve é interessante para analisar as relações entre direito e violência porque, nela, há a admissão, por parte do Estado, de uma certa violência legítima, através de um direito e, ao mesmo tempo, quando essa violência cruza certos limites, torna-se inaceitável para o direito e é por ele reprimida.

Para Benjamin (2011, p.128), a greve geral proletária, por consistir no mero abster-se de uma ação, e não dirigir-se a nenhum fim determinado, pode dar-se como "um puro meio, inteiramente sem violência". Ao mesmo tempo, essa violência não-violenta "é capaz de fundamentar e modificar relações de direito" (Benjamin, 2011, p.130) de forma imediata. A greve geral como "puro meio"

não acontece com a disposição de retomar o trabalho depois de concessões superficiais ou de qualquer modificação nas condições de trabalho, mas com a resolução de retomar apenas um trabalho totalmente transformado, sem coerção por parte do Estado. (Benjamin, 2011, p.143) 
A transformação trazida por essa prática não se coloca como um fim para os meios utilizados, mas se concretiza i-mediata-mente nos próprios meios. A violência como "puro meio" não se volta para algo além de si, mas apenas manifesta-se.

Em outros ensaios de juventude, como "Sobre a Linguagem em Geral e Sobre a Linguagem do Homem” e “A Tarefa do Tradutor”, Benjamin (2011) propõe uma concepção da linguagem como "puro meio", que opõe à concepção "burguesa" da linguagem. Para esta, a linguagem seria um meio voltado ao fim de representar ou de comunicar algo, ao passo que a linguagem como "puro meio" só comunicaria a si mesma.

Assim, Benjamin relaciona, de um lado, o mediato, a representação, a comunicação e o direito e, de outro, o imediato, a mera manifestação e o anômico. É essa polarização binária que Derrida se proporá a desconstruir.

\subsection{As duas tentações da desconstrução}

Ao citar Jacques Vergès, um advogado que trabalhava, é claro, dentro da lei, mas através do que chamava de "estratégias de ruptura", como exemplo da "fascinação admirativa exercida sobre o povo pela figura do 'grande' criminoso" (Jacques Mesrine, por exemplo, seria um exemplar mais óbvio), Derrida (2007, p.78) já vai sugerindo, antes de chegar a essa parte do seu argumento, a inserção da violência que rompe com o direito no interior do direito e da sua interpretação.

Com efeito, essa é a principal forma como Derrida desestabiliza as distinções traçadas por Benjamin em seu ensaio. Para ele, "aquilo que ameaça o direito pertence já ao direito, ao direito ao direito, à origem do direito" (Derrida, 2007, p.82). Ele volta ao exemplo da greve geral:

A greve geral fornece, assim, um fio condutor precioso, já que ela exerce o direito concedido para contestar a ordem do direito existente e criar uma situação revolucionária na qual se tratará de fundar um novo direito, se não sempre [...] um novo Estado.

A violência busca fundar um novo direito não tem como ser legítima no momento em que irrompe. Apenas a posteriori ela justificar-se-á. Por isso, ela deve calcar-se de alguma forma na ordem anterior, como é o caso do direito de greve. A fundação de um novo direito sempre "joga, por assim dizer, com algo de um direito anterior que ela estende, radicaliza, metaforiza ou metonimiza" (Derrida, 2007, p.97). Afinal, uma violência inteiramente descolada do direito 
não seria capaz de introduzir-se no âmbito do direito, de garantir ali um espaço a partir do qual poderia promover uma ruptura.

Para Derrida (2007), não só a legitimação de um novo direito só pode ser concebida retroativamente, mas também a sua inteligibilidade e interpretabilidade só serão produzidas a partir da sua instauração. O Estado é também um estado-de-coisas e um estado da leitura, o que implica em que toda interpretação do direito é determinada por um conjunto de estratégias de leitura ${ }^{1}$ produzidas pelas próprias instituições do direito. Assim, toda violência que repete o estado atual do direito faz-se legível, ao passo que toda violência que rompe com esse estado aparece como ilegível.

Benjamin (2011, p.155) escreve que

não é igualmente possível nem igualmente urgente para os homens decidir quando a violência pura realmente se efetivou em um caso determinado. Com efeito, apenas a violência mítica, não a divina, será reconhecida como tal com certeza.

Como vimos, Benjamin relaciona a violência que instaura e mantém o direito à esfera do significado e da comunicação, ao passo que a violência que o depõe está relacionada a uma linguagem que não comunica nada além dela mesma. A partir daí, Derrida (2007) coloca que toda legibilidade e compreensão decidível (possibilitando decidir se uma violência se efetivou ou não) estaria relacionada à violência do direito, enquanto a violência anômica caracterizarse-ia pela indecidibilidade da sua efetivação e pela ilegibilidade. O direito, igualmente, é da ordem do calculável, ao passo que a violência anômica é da ordem do incalculável.

Ocorre que, ao inserir a violência que depõe o direito no interior do direito, Derrida (2007, p.87) escreve que "há uma possibilidade de 'greve geral', um direito análogo ao de greve geral, em toda leitura interpretativa, e essa greve geral não é nem puramente "política" (pura fundação do direito), nem puramente "proletária" (pura deposição do direito). A violência do direito e a violência anômica convivem na interpretação.

Com efeito, Derrida (2007, p.87) identifica essas duas tentações - de fundar um novo direito e de destruir todo direito - às "duas tentações da desconstrução".

\footnotetext{
${ }^{1}$ Para uma discussão sobre estratégias interpretativas e suas relações com as instituições que as tornam possíveis em uma comunidade que, ao nosso ver, é compatível com a discussão sobre legibilidade aqui levada a cabo, ver Fish (1980, 1989).
} 
Assim, a violência desconstrutiva pensada por Derrida (2007, p.88) não seria nunca uma "estratégia de ruptura" pura (para voltar a Vergès), nem uma pura re-instauração, o que implicaria em uma pura repetição do estado anterior do direito, mas uma combinação indecidível das duas coisas, em que elas, permanecendo opostas, convivem.

O direito pode ser lido e compreendido segundo as formas vigentes de leitura, mas a partir dele não se pode decidir. Como a linguagem do direito sempre carrega algum grau de ambiguidade, sua aplicação depende sempre de uma decisão que não se reduz àquilo que está previsto (essa é a tese do realismo jurídico). Já a violência que rompe com o direito não pode ser compreendida ou lida enquanto tal, mas se manifesta em uma decisão "justa, histórica, política” (Derrida, 2007, p.130). Toda cisão é uma de-cisão.

Para Derrida (2007, p.130), "sob uma ou outra forma, o indecidível está dos dois lados e é a condição violenta do conhecimento e da ação. Mas conhecimento e ação estão sempre dissociados". O direito puro e simples pode ser conhecido, mas não pode agir. A violência anômica pode agir, mas não pode ser conhecida. Daí decorre que em toda violência que queira transformar o direito devem conviver as "duas tentações da desconstrução" - a violência do direito e a violência anômica - e só assim a desconstrução se opera.

\subsection{A eventualidade do evento}

Derrida (2007, p.83) escreve que “aqueles que dizem 'nosso tempo', pensando então 'nosso presente' à luz de uma presença futura anterior, não sabem muito bem, por definição, o que dizem”. Segundo ele, “é justamente nesse não saber que consiste a eventualidade do evento, aquilo que se chama ingenuamente de sua presença”.

O conceito de evento é essencial aqui. Aquilo que realmente acontece, para Derrida, o verdadeiro evento, não apenas se segue ao anterior, mas irrompe como absolutamente irredutível, incomensurável e incalculável a partir do que o precede. O evento é a irrupção do radicalmente novo. A "eventualidade do evento", portanto, está diretamente ligada à sua ilegibilidade anterior.

Por isso, Derrida distingue o futuro, que pode ser calculado a partir da continuidade do presente, do porvir, que, por não pertencer às possibilidades do presente, permanece sem previsibilidade ou inteligibilidade. $\mathrm{O}$ evento abre o presente ao porvir.

Derrida, como Benjamin, está interrogando-se sobre a possibilidade do radicalmente novo, da ruptura radical. A crítica da violência pode ser lida como uma filosofia do evento. A 
diferença, contudo, entre Derrida e Benjamin, é que, enquanto este quer uma pura ruptura, em que o ciclo do direito possa ser destruído de uma vez por todas, Derrida insere a ruptura na continuidade, e assim coloca o Direito em devir sem, contudo, destruí-lo. O ciclo do direito torna-se, então, uma espiral, que ainda gira, mas sai do seu eixo. Por isso, não se trata de destruição, mas de desconstrução.

\section{Interpretar a manifestação}

Raquel Rolnik (2013, p.8) abre sua apresentação de "Cidades Rebeldes" comentando o editorial de um periódico francês. Ela descreve o artigo como exemplo da "ladainha do fundamentalismo neoliberal, apontando o elevado custo do trabalho, a alta carga tributária e a corrupção como os responsáveis pelo grande descontentamento manifesto nas ruas". Logo em seguida, faz referência a uma "guerra de interpretações das vozes rebeldes" e elogia a "bela e forte tentativa de interpretação das chamadas revoltas de junho" empreendida pelos pensadores de esquerda reunidos na compilação.

Evidentemente, a interpretação das "revoltas de junho" a partir de uma ortodoxia neoliberal mal merece o nome "interpretação", sendo antes a imposição demasiado fácil de um vocabulário pré-pronto que traz, consigo, suas conclusões. A pretensa interpretação parte do seu ponto de chegada, e toma por evidente aquilo que deveria aferir: o que dizem realmente "as vozes das ruas". Esse problema, levado a sério, deveria levantar necessariamente a dificílima questão epistemológica: como é possível aferir o que "significa" uma manifestação que, além de plural, sequer conta com lideranças ou com um centro de organização; que se forma - como têm-se formado os protestos contemporâneos ligados às redes sociais - de forma espontânea e “rizomática"? Não parece estar claro que isso seja sequer teoricamente possível ou que seja, em termos práticos, verossímil.

O problema, portanto, parece estar em outra parte: na palavra "interpretação". Não se trata simplesmente de rejeitar interpretações simplistas, impositivas ou equivocadas do fenômeno em questão, mas antes (logicamente antes) disso, de responder à questão se um fenômeno dessa natureza precisa de interpretação, se sua interpretação é possível e desejada, e em primeiro lugar o que significa interpretar algo.

O intérprete é aquele que descobre o sentido por trás de algo. Interpretar um fenômeno implica em que seu sentido não se dá obviamente, que é preciso descobrir o seu sentido oculto.

O que é interpretar uma manifestação, se tomarmos tanto o verbo quanto o substantivo ao pé da letra? Como vimos, Benjamin (2011) relaciona, em sua crítica da violência, a ordem a 
manifestação à do imediato, e à opõe à ordem do mediato. Aquilo que meramente se manifesta difere daquilo que relaciona-se como meio a um fim. Essa distinção é simétrica à oposição entre a linguagem como "puro meio" e a linguagem da representação. A manifestação seria então, por definição, aquilo que não representa nada, que não se refere a nada, que não simboliza ou significa nada, mas apenas manifesta (representa, significa) a si mesmo.

É claro que esse não é o único sentido da palavra "manifestação", e que ninguém tem que tê-lo em mente ao usar a expressão como sinônimo de "protesto". Não obstante, a reflexão pode iluminar a questão que nos importa aqui, isto é, em que medida faz sentido falar em interpretar uma manifestação.

Não seria uma manifestação de rua algo cujo sentido, a final, é evidente? Em outras palavras, não estaríamos errados em procurar mais atrás ou mais fundo um sentido para além do que claramente se dá a ver? Não deixamos, assim, de vê-lo? Uma manifestação de rua, no sentido etimológico da palavra, é uma coisa obvia. Ela está ob via, ou seja, de frente à rua, e é impossível não vê-la. Mais que isso, é impossível ignorar seus efeitos, pois eles são de natureza material e concreta - a passagem torna-se impossível. Sua apresentação é a forma concreta e palpável da aporia, do não-caminho.

Esse exercício sobre as palavras sugere certas questões que podemos explorar. Em princípio, as seguintes: a) Se não há pelo menos certos aspectos das manifestações que não tenham nada a ver com o plano daquilo que pode ou deve ser interpretado; e b) Em que medida aquilo que a interpretação pode, de fato, fazer com esses fenômenos é desejável e positivo - e aqui deveríamos ter em mente a profunda desconfiança pós-estruturalista/pós-colonialista com a relação conhecimento/poder. Descobrir (isto é, conhecer) o sentido das manifestações não poderia ser uma forma de exercício de conhecimento como poder, da parte das instituições aptas a produzir esse conhecimento, sobre o que/quem se manifesta? Não deveríamos ficar atentos, aí, à possibilidade de violência epistêmica, mesmo diante das mais nobres intenções? A crítica da violência que discutimos aqui deve fazer-se útil para que possamos compreender, de forma mais rica, a dinâmica entre as diferentes dimensões que parecem conviver nessa problemática.

Com efeito, se as palavras "manifestação" e "protesto" foram usadas de forma quase totalmente intercambiável na descrição dos acontecimentos, elas aparecem, no sentido em que agora nos propomos a entendê-las, como praticamente antagônicas. Se a manifestação não significa nada, mas apenas dá-se a si mesma, todo protesto é protesto contra e/ou por alguma coisa. O protesto é transitivo, digamos, enquanto a manifestação é intransitiva. Essa distinção, logo percebe-se, corresponde àquela estabelecida por Derrida entre a dimensão legível/indecidível e a dimensão ilegível/decidível da violência. A manifestação é por definição 
ilegível, mas é decisiva, se impõe, enquanto o protesto deve ser legível pelo seu destinatário, mas não decide por ele. Seguindo ainda o paralelo, a dimensão do legível pertence ao mundo do direito, ao passo que a dimensão ilegível é absolutamente externa ao direito. Para Derrida, ambos aspectos da violência têm seu papel, já que o primeiro garante o seu ingresso à dimensão do jurídico, ao passo que o segundo permite a inserção, nesse âmbito, de uma ruptura.

Daqui em diante analisaremos a discussão teórica sobre as manifestações/protestos tendo em mente essa convivência/indecidibilidade entre, de um lado, a ordem do símbolo e da representação e, de outro, a do "puro meio".

\subsection{Agendas}

Rolnik (2013, p.8) continua sua introdução afirmando que "os autores desta coletânea apontam várias agendas como o epicentro do terremoto”. Não precisamos, claro, nos apressar a condenar essa iniciativa, que é necessária, mas devemos pensar sobre ela. Em especial, por enquanto, consideremos as expressões "agenda" e de "epicentro".

Toda agenda pertence, eminentemente, à ordem do calculável. O agendado, o que se agenda, é projetado com data e hora específicas. É, portanto, da ordem do futuro, e não do porvir; do antevisto, e não do que irrompe. Uma agenda nada mais é do que um quadro de referência pré-estabelecido do futuro. Nenhum evento, no sentido prenhe da palavra, pode ser, portanto, agendado. Uma descrição das agendas de um movimento só pode incluir aquilo que já se conhece, nunca o radicalmente novo.

O mesmo vale para a expressão "pautas", usada² como sinônimo de "agendas". Pautar alguma coisa não é senão impor sobre ela uma regra. Pauta é um papel regrado, ou o molde com que se regra esse papel; um regulamento, um modelo, ou ainda um rol, uma lista, uma relação. Pautar um movimento é, portanto, sem meias palavras, impor sobre ele uma normatividade, normatizá-lo e normalizá-lo a partir de alguma autoridade.

Isso não é, em si, um problema. Derrida (2007) escreve que a justiça, embora seja da ordem do incalculável, exige que calculemos, pois apenas através do cálculo é que ela pode efetivar-se em alguma medida (o que é dizer, desde já, de forma não-absoluta).

\footnotetext{
${ }^{2}$ Lincoln Secco (2013, p.72), por exemplo, introduz uma distinção entre "pauta popular" e "pauta de massas", como veremos em seguida.
} 
Esse cálculo inclui, por exemplo, a possibilidade de codificação como direito. Isso não é em si um mal. É importante e necessário.

O problema está, antes disso, na ideia de epicentro. A ideia de centralização traz consigo o espectro do reducionismo e da totalização. É preciso calcular, mas o risco é reduzir o fenômeno ao calculável, àquilo que pode ser conhecido, medido, normalizado. Como já sugerimos, é possível que algo essencial sobre as manifestações escape a esse tratamento. Interpretações totalizantes, que pretendam reduzir o todo do fenômeno a algum princípio já conhecido e já conhecível, arriscam suprimir dele justamente aquilo que poderia ter de novo apagar "a eventualidade do evento". Isso independentemente de serem interpretações "de direita" ou "de esquerda". A esse perigo não está menos sujeito o intelectual crítico do que o periódico neoliberal.

Uma abordagem crítica que não queira barrar as possibilidades criativas daquilo que observa nas ruas deve, assim, se partirmos das observações aqui esboçadas, manter ativa a indecidibilidade entre o direito e o não-direito, o legível e o ilegível, o decisivo e o indecidível, que marca a violência desconstrutiva.

\subsection{Pautas}

O historiador da USP Lincoln Secco (2013, p.72) traça em seu artigo uma distinção entre "pauta popular" e "pauta de massas":

De um lado, a pauta popular, organizada de baixo para cima nos primeiros dias, na qual era central a questão da tarifa de transporte, introduzida pelo Movimento Passe Livre (MPL). De outro, uma pauta que veio de cima para baixo. Esta era a pauta de massa. A questão aqui não é o conteúdo, mas a forma, ou seja, o que importa é como a "vanguarda" interpela os demais. A linguagem de cima é apelativa como a publicidade. A de baixo assemelha-se ao jogral, escolhido pelo MPL em contraposição ao tradicional uso de carros de som e palanques.

A distinção estabelecida por Secco é interessante e iluminadora. Em especial, ela cumpre a importante função de desconstruir a violência interpretativa exercida pelos meios de comunicação, através do grande aparato institucional de que dispõem, ao pautar de cima para baixo os protestos.

Ao mesmo tempo, sua abordagem da "pauta popular" parece demasiado inocente quanto à sua própria violência, à sua própria autoridade. É claro que há uma diferença entre a forma como o MPL "pauta” as manifestações e como a grande mídia o faz. O que parece 
escapar, contudo, ao acadêmico, é que o enquadramento de certos conteúdos como "pauta popular" não se dá por si mesmo. Ordenar e classificar esses conteúdos, bem como instituir uma distinção entre tipos de pautas (implicando uma diferença de legitimidade) está longe de ser possível como uma operação neutra e não-violenta. Por mais "populares" que sejam certas pautas, sua classificação como tal por qualquer agente dependerá sempre de um exercício de conhecimento como poder da parte deste, sob a sua autor-idade.

$\operatorname{Secco}(2013$, p.72) faz bem ao chamar a atenção para o fato de que "apesar de a maioria dos jovens manifestantes usar a internet para combinar os protestos, os temas continuam sendo produzidos pelos monopólios de comunicação". Ao mesmo tempo, resta a questão: Quem está autorizado a produzir esses temas? É possível, com efeito, que o formato das manifestações como as temos visto impossibilite, por uma carência de "meios de produção", que elas próprias produzam seus temas. Nesse caso, talvez não haja outra alternativa a não ser estender aos intelectuais o papel de produzi-los, de "pautar" a manifestação. A consciência da inevitável violência dessa operação deve, contudo, ser ressaltada, para que haja a devida vigilância.

\subsection{O enigma de junho}

Ao abrir seu artigo, Secco (2013, p.71) refere-se às “Jornadas de Junho de 2013" como um "enigma". A mesma palavra apareceu no título de uma série de posts de blog de Idelber Avelar sobre "O Enigma de Junho". Logo nas primeiras linhas do primeiro post, Avelar (2014) explica o título, citando uma canção de Bob Dylan:

Não foram poucos os que disseram que não há nada de diferente acontecendo aqui. Outros tantos disseram que está acontecendo algo novo, mas que já sabemos do que se trata. A contrapelo desses dois grupos, tanto agentes sociais quanto analistas de várias disciplinas já reconheceram que está acontecendo algo que ignoramos: something is happening here and you don't know what it is tem sido uma espécie de mantra frequentemente reiterado acerca dos recentes acontecimentos no Brasil.

No restante da série de posts, Avelar se dedica também a uma interpretação das "manifestações de junho", a partir de uma série de ângulos. Interessa aqui, porém, antes de tudo a citação de Dylan que, inconscientemente ou conscientemente ${ }^{3}$ da parte do autor, parece expressar precisamente aquilo que aqui discutimos.

\footnotetext{
${ }^{3}$ Avelar é influenciado pela desconstrução, e escreveu (Avelar, 2009) especificamente sobre o tema da violência em Derrida e Benjamin.
} 
Você sabe que algo está acontecendo aqui, mas você não sabe o que é. A frase é a expressão quase perfeita da "eventualidade do evento". Aquilo que acontece - o evento - só pode ser "algo", nunca uma coisa determinada. Saber o que é implica em exercer uma forma de conhecimento - portanto de poder/violência - sobre o objeto, o que é incompatível com o evento. Sempre que algo realmente acontece - algo que não apenas reproduz o que havia, mas sim irrompe como novo -, por definição não sabemos o que é.

Se há um ponto em que a frase de Dylan não condiz com a nossa discussão sobre o evento, é porque você nunca sabe - isto é, nunca tem conhecimento decidível - sobre o fato de

haver um evento ( "you know something is happening here”). Porque ele só fundará sua própria legibilidade a posteriori, o evento escapa ao conhecimento. Ele se dá como que em um ponto cego. Por isso, se pretendemos buscar compreender o que há de novo, nunca devemos fazê-lo rapidamente demais, com demasiada pressa. É preciso dar tempo ao evento, e fazê-lo sem a certeza de que de fato haja algum.

\subsection{Antipartidarismo e violência interpretativa}

Um dos exemplos mais marcantes de como as interpretações vindas da esquerda são capazes de facilmente abafar a possível novidade sob uma classificação preconcebida é a sua rígida condenação a um certo "antipartidarismo" que surgiu nas manifestações. Secco (2013, p.72) toma por evidente que "aqueles que expulsaram as esquerdas das ruas" - ou seja, os grupos que reagiam violentamente às bandeiras de partidos - eram um mero produto da doutrinação midiática, de uma ideologia imposta de cima para baixo. Rolnik (2013, p.11) não demora em classificar o mesmo fenômeno como "fascista". Essa interpretação foi comprada quase imediatamente pela grande maioria da esquerda que, embora supostamente descrente das atuais formas da democracia representativa, ainda se apega aos seus partidos. Mas não estaria essa esquerda se apressando em suas conclusões?

É claro que a tendência "antipartidária” em questão era confusa e sem dúvida mal direcionada em seus alvos. A violência contra manifestantes com bandeiras é claramente perniciosa. Mas interpretar essa violência extraviada como uma evidente versão do fascismo é descabido. Que a rejeição aos partidos seja característica do fascismo não significa que haja algo essencialmente fascista sobre a rejeição à representação partidária. Afinal, se os mesmos 
intelectuais e acadêmicos diagnosticam uma profunda crise da ideia de representação, por que então ser tão rápidos em identificar esse sentimento ao fascismo? Porque presumir que ele só pode ter sido produzido, "de cima para baixo", pela mídia?

Vladimir Safatle, antes de 2013, (2012, p.55) já afirmava o seguinte:

Podemos não saber o que vai acontecer no futuro, que tipo de nova organização política aparecerá, mas sabemos muito bem onde acontecimentos não ocorrerão. Com certeza não nas dinâmicas partidárias. Você tem uma força de pressão enquanto está fora do jogo partidário. Quando entrarmos nele, tal força diminui. Então, conservem este espaço!

Uma violência muito intensa claramente se manifesta, de forma ainda precária e sem um programa propositivo, mas ela parece colidir com tudo aquilo que procura representá-la de alguma forma. Partir imediatamente para conhecê-la em termos de alguma teoria é procurar representá-la por outros meios e barrar a possibilidade do novo. Talvez reconhecer que algo aí acontece, e que ainda não sabemos o que significa, seja mais interessante.

O que talvez não queiramos ver e relutemos em aceitar é que não podemos facilmente determinar que aquilo que irrompe nos protestos pertença ao campo político da esquerda ou da direita. Daí pode vir tanto a radicalização da democracia e da justiça quanto o mal radical, o pior, o retorno à ditadura. Dar espaço para que isso permaneça indecidível é fazer uma aposta no evento, e é a sua única chance, mas implica necessariamente em um grande risco. Como disse Guimarães Rosa, “viver é perigoso”. Não se pode esperar uma revolução previsível, com manual de instruções ou mapa. Revoltar-se é, como propõe Žižek (2012b), sonhar perigosamente. Por isso mesmo, é necessária muita atenção. É preciso - para usar de um oximoro - sonhar de forma vigilante.

\subsection{O clinch político}

Um ano antes de lançar o livro sobre as manifestações brasileiras a partir do qual estamos discutindo - e que esse tipo de evento irrompesse no Brasil -, a editora Boitempo tinha organizado uma compilação parecida sobre os movimentos agrupados sob a rubrica "Occupy" ao redor do mundo. Para esse volume, foi traduzido um artigo de Slavoj Žižek sobre o movimento Occupy Wall Street, que foi proferido pelo filósofo, em forma abreviada, através de um jogral durante a ocupação da Praça Zuccotti, em 2011. Em uma passagem marcante, Žižek (2012a, p.18) diz o seguinte: 
Os manifestantes devem ter cuidado não só com os inimigos, mas também com os falsos amigos que fingem apoiá-los e trabalham duro para diluir o protesto. Da mesma forma que tomamos café sem cafeína, cerveja sem álcool e sorvete sem gordura, eles tentarão transformar os protestos num gesto moralista inofensivo. No boxe, o clinch é o movimento de abraçar o corpo do oponente com um ou dois braços para prevenir ou evitar socos. A reação de Bill Clinton aos protestos em Wall Street é um exemplo perfeito de clinch político; Clinton acha que os manifestantes são, "no final das contas, algo positivo", mas se diz preocupado com a nebulosidade da causa: "eles precisam apoiar algo específico, e não somente ser contra, pois, se você é simplesmente contra, alguém acaba preenchendo o vazio que você criou", disse ele. Clinton sugeriu que os manifestantes apoiassem o plano de empregos do presidente Obama, que, segundo ele, criará "milhões de empregos ao longo do próximo um ano e meio".

O clinch de que fala Žižek já tinha sido descrito quando Benjamin (2011) apontou que o direito, diante de uma violência que se apresenta como externa a ele, procura impor fins de direito a essa violência, capturando-a assim no ciclo vicioso entre a violência que instaura e a violência que conserva o direito. Para Žižek (2012a, p.18), "nesta etapa, devemos resistir precisamente a uma tradução assim apressada da energia das manifestações para um conjunto de demandas pragmáticas "concretas"'. Só assim poderíamos evitar que a estratégia do clinch bloqueasse as possibilidades realmente inovadoras do evento.

"Sim, os protestos criaram um vazio - um vazio no campo da ideologia hegemônica", continua Žižek (2012a, p.18), “e será necessário algum tempo para preenchê-lo de maneira apropriada posto que se trata de um vazio que carrega consigo um embrião, uma abertura para o verdadeiro Novo". Žižek, como Derrida ou Benjamin, também está preocupado com as condições de possibilidade (e de impossibilidade) de uma verdadeira ruptura, e da irrupção do novo. Em suma, com a filosofia do evento. Ele chama atenção ao perigo de reduzir demandas ainda não articuladas a meros fins de direito, desde já legítimos e possíveis.

A metáfora de Žižek do clinch político nada mais é do que outra forma de falar da violência interpretativa que mantém o direito.

\section{6. "Pacíficos" e "baderneiros"}

Vários dos artigos reunidos comentam a "clivagem entre 'pacíficos' e 'baderneiros"” (Rolnik, 2013) estabelecida, a partir de um dado momento, pelo discurso midiático que cobriu as manifestações. Trata-se de um exemplo explícito da violência interpretativa conservadora que é exercida pelas instituições do status quo. "A tela que nos apresenta as manifestações encontra dividida”, observa Silvia Viana (2011, p.57), “de um lado, imagens verde-e-amarelas, 
de outro, cenas vermelhas". "Desde que depurada dos vândalos, a passeata torna-se aceitável" (Secco, 2013, p.72), mas, por isso mesmo, faz-se inofensiva - e atente-se aqui para o uso do termo "passeata", em lugar de "protesto" ou "manifestação".

Com efeito, a manifestação meramente legítima torna-se uma passeata. Um grupo de cidadãos-no-exercício-do-seu-direito-de-manifestação não pode trazer nenhuma interrupção no fluxo de auto-reprodução do direito. A demanda "legítima" expressa aí já faz parte do mundo do direito, e pode ser plenamente absorvida por ele. A manifestação perde o seu potencial de promover uma ruptura no direito.

Seria interessante perceber, contudo, que a violência interpretativa em questão é mais inteligente do que parece à primeira vista, pois não tem apenas um lado, e sim dois lados complementares. Se, de um lado, os "manifestantes pacíficos" não podem senão reproduzir o estado presente do direito, de outro os "vândalos" - manifestantes cujas demandas não são evidentemente legítimas, que oferecem algum desafio ao direito, ou que exercem alguma violência (em sentido físico ou não) externa a ele -, interpretados como puramente alheios ao direito, perdem seu canal de entrada no âmbito do direito.

Vista assim, a violência interpretativa promovida pela mídia, ao separar "legítimos" e "vândalos", não fez menos do que separar e isolar os dois elementos da violência descrita por Derrida - de um lado, a violência do direito, legível mas incapaz de decidir, de outro, a violência externa ao direito, ilegível e decisiva. Como qualquer das duas, a partir dessa pura separação, torna-se incapaz de transformar o direito, a cisão promovida pela mídia, talvez por uma certa intuição inconsciente que os mecanismos conservadores parecem capazes de desenvolver, consegue promover um molde de interpretação que desarticula o potencial da manifestação de transformar o direito.

\subsection{Protestos em nome do direito e contra o direito}

O jurista e acadêmico Jorge Luiz Souto Maior (2013, p. 83) começa seu artigo na compilação encarnando de forma muito direta a voz das manifestações:

A população quer mais serviços públicos de qualidade. Querem a atuação de um Estado social, pautada pelo imperativo de uma ordem jurídica que seja apta a resolver nossa grave questão social, notadamente a da desigualdade social.

Novamente, caberia perguntar que epistemologia autoriza essas conclusões, ou qual instância atribui ao autor a autoridade para definir tais posições - ainda mais em termos que 
parecem tão pouco intuitivos para um desejo das massas. Novamente, a violência que conhece é do mesmo tipo que a violência do direito. Por um lado, é violenta porque regula. De outro, é necessária para que direitos possam ser concretizados.

A seguir, Souto Maior (2013, p.83) ressalta o êxito das manifestações em terem obtido seu reconhecimento como "manifestações políticas legítimas". Com efeito, a conquista dessa parcial legitimidade, dessa dimensão legítima, é essencial para o ingresso dessa violência ao âmbito do direito. Ao mesmo tempo, como já vimos, uma violência que chegue a ser legível como inteiramente legítima já não pode transformar o direito, pois apenas reproduz e reafirma o conteúdo do direito, participando do ciclo da sua auto-reprodução.

Mas é a partir daqui que a discussão desse jurista (e Juiz do Trabalho) se mostra uma das mais interessantes para nossa discussão sobre o direito. $\mathrm{O}$ autor escreve o seguinte:

Ocorre que, adotando-se os pressupostos jurídicos atuais, os movimentos sociais, quando se mobilizam em atos políticos para lutar por direitos, não estão contrários à lei. Além disso, não podem ser impedidos de dizer que determinadas leis, sobretudo quando mal interpretadas e aplicadas, têm estado, historicamente, a serviço da criação e da manutenção da intensa desigualdade que existe em nosso país.

Nesse curto parágrafo, o autor dá expressão às diferentes formas como a violência pode se relacionar com o direito. Em certos casos e em certos sentidos, como já foi dito, os movimentos “não estão contrários à lei”. Além disso, porém, “determinadas leis" têm estado a serviço de um círculo historicamente vicioso e violento do direito, sobretudo quando mal interpretadas e aplicadas.

Há aqui duas formas como o direito pode ser rejeitado. Pode ser rejeitado por conta do conteúdo de suas leis, ou pode ser rejeitado em certas más interpretações, sem que em teoria o seu conteúdo seja transformado. É claro que uma distinção clara entre o conteúdo interpretado e a sua interpretação não pode ser mantida coerentemente por muito tempo, mas a ênfase nessa distinção ajuda a mostrar como uma revolução na ordem de interpretação e aplicação do direito - isto é, nas estratégias interpretativas consideradas possíveis em uma instituição - já é de certa forma uma revolução no direito.

Assim, se os movimentos de protesto têm, de um lado, legitimidade, de outro eles devem chocar-se, seja com uma lei que historicamente é perniciosa, ou com uma interpretação que possibilita a reprodução do círculo vicioso do direito. Não devemos, por sinal, deixar de atentar à semelhança entre a menção de Souto Maior à "criação e manutenção" da desigualdade com o ciclo benjaminiano entre a violência que instaura e a que mantém o direito. 


\subsection{Demandas utópico-realistas de direitos}

Souto Maior (2013, p.85) passa então a competentemente arrolar argumentos jurídicos e principiológicos através dos quais certas demandas que atribui às manifestações podem ser compreendidas não apenas como não-contrárias a lei, mas como demandas legítimas do ponto de vista do direito. Cito-o em bloco, como jurisprudência:

Os movimentos sociais [...] pretendem demonstrar, em verdade, que agem amparados pela Constituição Federal, nossa Lei Maior, a qual, instituída a partir da noção de Estado democrático de direito, prevê como objetivos fundamentais da República Federativa do Brasil: i) construir uma sociedade livre, justa e solidária; ii) garantir o desenvolvimento nacional; iii) erradicar a pobreza e a marginalização e reduzir as desigualdades sociais e regionais; iv) promover o bem de todos, sem preconceitos de origem, raça, sexo, cor, idade ou quaisquer outras formas de discriminação. [...] A constituição, fazendo menção às relações internacionais, deixa claro que o Estado brasileiro se rege pelos princípios da prevalência dos direitos humanos (inciso II, art. $4^{\circ}$ ); da defesa da paz (inciso VI, art. $4^{\circ}$ ); da solução pacífica de conflitos (inciso VII, art. $4^{\circ}$ ); e da cooperação entre os povos para o progresso da humanidade (inciso IX, art. $4^{\circ}$ ), não sendo nem mesmo razoável supor que com relação aos movimentos políticos internos, de natureza reivindicatória, seja considerado que o império da lei se dê para calar e criminalizar aqueles que, bem ao contrário, pretendem exatamente que os preceitos constitucionais se efetivem. Esse agir político é, ademais, o pressuposto básico da cidadania, o princípio fundamental da República (inciso II, art. $1^{\circ}$ ).

O autor argumenta ainda que os protestos decorrem da inércia dos poderes públicos em efetivar os direitos constitucionais, e conclui que "o que vivemos no Brasil há anos [...] é uma resistência ao cumprimento da ordem jurídica constitucional, pautada pelos direitos humanos e pelos preceitos do direito social" (Souto Maior, 2013, p.87). Assim, ele coloca as demandas das manifestações como demandas pautadas no direito, mas que, ao mesmo tempo, o direito historicamente vem-se recusando a cumprir, em parte em virtude das formas de interpretação (dos princípios constitucionais, por exemplo) vigentes.

A violência das ruas pode, assim, manifestar-se como uma violência ao mesmo tempo legitimada pelo direito, e contrária ao direito no sentido de que pretende subverter a ordem de leitura historicamente reproduzida até então.

Žižek (2012a, p.19), no artigo antes mencionado, afirma que "a arte da política também está em insistir numa existência particular que, apesar de radicalmente 'realista', perturba o 
núcleo da ideologia hegemônica", ou seja, uma demanda que, embora "plausível e legítima", é impossível de efetuar sem uma mudança radical do estado das coisas. Žižek dá como exemplo desse tipo de demanda, no caso americano, o plano de saúde universal; Safatle (2012) fala da demanda, no Chile, por educação pública gratuita e de qualidade. Que demanda cumpriria essa função no cenário brasileiro - uma demanda ao mesmo tempo imediatamente exigível e considerada, pelos nossos moldes de pensamento, impossível?

Essa demanda, no cenário atual, e especialmente pensando a partir das manifestações de junho de 2013, não poderia ser outra senão a demanda pelo passe livre.

O Movimento Passe Livre (2013, p.16), em seu manifesto, assume o "discurso do transporte como direito". Sua demanda pelo transporte público gratuito para todos é baseada em uma interpretação da ordem constitucional. Ao mesmo tempo, essa interpretação precisa enfrentar o "véu de argumentos técnicos que [esconde] os conflitos sociais e econômicos por trás da gestão do transporte". Esses "argumentos técnicos", de modo geral, podem agrupar-se sob o bordão ideológico "não existe almoço grátis" - um dos mais repetidos nas discussões sobre o tema. São tais componentes ideológicos, por menos resistentes que sejam a uma análise mais profunda, que dão aparência de impossibilidade a interpretações do direito como a que embasa a demanda pelo passe livre.

João Alexandre Peschanski, em seu artigo, enfileira argumentos que progressivamente transportam a demanda pelo passe livre do âmbito da utopia para o da razoável e imediata necessidade. Ainda assim, ao final, reconhece:

Enfrentar o equilíbrio político, supraclassista e suprapartidário, que sustenta a sociedade do automóvel, é um dos principais desafios dos movimentos sociais que se organizam em torno da reivindicação do transporte público gratuito (Peschanski, 2013, p.63).

Assim, a exigência do transporte público gratuito se dá através de uma leitura feita a contrapelo da ordem estabelecida. A leitura vigente dos princípios constitucionais não é nada menos do que a leitura da sociedade do automóvel. Pensar que a defesa do automóvel não é princípio constitucional é ignorar que ela invade, através da ordem de leitura desenvolvida na nossa sociedade, as leituras possíveis desses princípios. Fazer uma leitura contrária a esses interesses não é menos que uma subversão das formas de leitura do direito.

Não obstante, essa violência que rompe é, na sua impossibilidade, possível. “A difusão de uma alternativa utópico-realista rompe o marasmo da política sem questionamentos, dos pactos consensuais", afirma Peschanski (2013, p.63), e assim pode articular "novos discursos e 
ideologias". A estratégia de ruptura é utópica e realista ao mesmo tempo, porque deve exigir o impossível de forma imediata. Se esse ato performativo tiver sucesso, uma nova ordem de leitura será instaurada, através da qual as leituras antes possíveis soarão absurdas, e as antes absurdas mostrarão sua racionalidade.

\subsection{Um passo atrás}

Logo após sua sugestão pelas demandas ao mesmo tempo realistas e capazes de desestabilizar a ordem estabelecida, Žižek (2012a, p.19) dá um passo atrás e afirma:

Entretanto, é igualmente importante que permaneçamos ao mesmo tempo retirados do campo pragmático das negociações e propostas "realistas". O que se deve ter em mente é que qualquer debate, aqui e agora, necessariamente permanece como um debate no território do inimigo: é preciso tempo para posicionar o novo conteúdo. Tudo o que dissermos nesse momento pode ser tomado (ou recuperado) de nós - exceto o nosso silêncio. Tal silêncio, tal rejeição ao diálogo, a todas as formas de clinch, são o nosso "terror", agourento e ameaçador como deve ser.

Por que o momento da ruptura deve ser um momento silencioso? Porque a totalidade da dimensão do legível ainda está tomada pela ordem precedente. Toda tentativa de expressão, nesse momento, será lida através dessa ordem de leitura, que só poderá levar à repetição do anteriormente possível, isto é, a "tomar" ou "recuperar" os discursos para o ciclo de refundação da legibilidade anterior do direito. Como a dimensão da expressão e da compreensão, e portanto a das demandas legíveis por direitos, ainda está sob a autoridade antiga, esse é o momento em que uma estratégia de ruptura é necessária, e essa estratégia não é da ordem da expressão, mas do silêncio. Ela se resume à interrupção das atividades, que procura criar, desde já, um espaço a partir do qual possa irromper o novo.

Como afirma Rolnik (2013, p.12) na conclusão de seu texto, "as propostas alternativas ao modelo dominante precisarão ter seu tempo de formulação e experimentação”. É natural que sejam, por enquanto, incompreensíveis e insustentáveis. É preciso, então, dar um passo atrás nesse momento, e pacientemente insistir em uma pura ruptura.

\subsection{Direito à cidade, ação direta e "puro meio"}

Paradoxalmente, as estratégias de simples ruptura devem ser, ao mesmo tempo que pacientemente mantidas, e ao mesmo tempo que recusam toda proposta de conhecimento da sua 
natureza, imediatas em sua manifestação. A violência como "puro meio", no pensamento de Benjamin (2011), não projeta seus efeitos para o futuro, mas se confunde com eles de imediato. $\mathrm{O}$ que significa isso?

Chegamos aqui ao que talvez seja o aspecto mais original e interessante da luta pelo passe livre e pelo direito à cidade. "Se a retomada do espaço urbano aparece como objetivo dos protestos contra a tarifa", afirma o Movimento Passe Livre (2013, p.16), ela "também se realiza como método". A retomada do espaço urbano não é apenas o fim a que se dirigem as práticas (o "método") do movimento. Ela se realiza nessas próprias práticas, e portanto de modo imediato:

\begin{abstract}
A ação direta dos trabalhadores sobre o espaço urbano, o transporte, o cotidiano da cidade e de sua própria vida não pode ser apenas uma meta distante a ser atingida, mas uma construção diária nas atividades e mobilizações, nos debates e discussões. O caminho se confunde com o próprio caminhar. (Movimento Passe Livre, 2013, p.17)
\end{abstract}

A prática de ação direta do movimento passa, assim, a mostrar-se como a realização contemporânea daquela violência como "puro meio" que Benjamin (2011) identificava, à sua época, com a greve geral proletária, no âmbito político, e com o diálogo aberto no campo das relações interpessoais. Com efeito, a ocupação e "ressignificação" dos espaços públicos (parece tratar-se antes de uma "reutilização", a atribuição de um novo uso, e não um novo significado aos espaços) realiza, de forma imediata, tanto uma interrupção da reprodução contínua da ordem precedente, quanto a abertura de um espaço em que o simples diálogo pode se dar de forma livre e inovadora.

David Harvey (2013, p.34) expressa-o melhor:

O direito inalienável à cidade repousa sobre a capacidade de forçar a abertura de modo que o caldeirão da vida urbana possa se tornar o lugar catalítico de onde novas concepções e configurações da vida urbana podem ser pensadas e da qual novas e menos danosas concepções de direitos possam ser construídas. $\mathrm{O}$ direito à cidade não é um presente. Ele tem de ser tomado pelo movimento político.

O direito à cidade não é um presente. Ele não está dado de antemão, e ele não se faz presente, ainda, no presente. Sua legibilidade, no âmbito das instituições jurídicas, ainda está por instituir, e não será possível enquanto o direito utilizar-se da violência que tem em mãos para reproduzir-se a si mesmo.

Na medida, porém, em que "novas concepções e configurações da vida urbana", bem como "novas e menos danosas concepções de direito" possam ser pensadas, em espaços que as 
possibilitem, e performatizem sua recém-descoberta possibilidade, uma nova ordem de leitura do direito pode ser instituída, de modo a introduzir o direito à cidade na lista dos direitos legíveis, compreensíveis e exigíveis segundo a ordem jurídica. Mas essa refundação só será possível se uma ruptura abrir, antes, o espaço para ela.

Nessa discussão, é interessante a análise do artigo de Silvia Viana (2013, p.56), em que a autora, ecoando a brincadeira de Žižek, fala de um "protesto sem protesto", em que "a bandeira que os unia, e era levantada nas ruas, [...] era a própria ocupação do espaço”. Para a autora, essas "mobilizações pacíficas", em que "importa ocupar o espaço público, difundir as ideias, ampliar o debate, unir as pessoas, participar", indicam um momento em que o protesto perdeu a sua relevância política. "O protesto que assim merece ser chamado" é, para Viana (2013, p.57), “em si mesmo, violento".

Ao opor o protesto que meramente ocupa o espaço público, une as pessoas e abre espaço ao diálogo, ao protesto "violento" (o único que merece o nome "protesto"), a autora não tem em conta a violência que se traduz no mero ato de ocupar o espaço público - justamente a violência como "puro meio" que acabamos de discutir, a violência que rompe a marcha do direito de forma paradoxalmente não-violenta. Em certo sentido, ela tem razão em dizer que trata-se de um protesto sem protesto, pois é um "protesto" que não protesta por nada - uma simples e imediata manifestação.

Curiosamente, nas últimas linhas do seu texto, Viana (2013, p.58) diz o exato oposto do que disse antes, embora não pretenda se referir a fenômenos da mesma ordem. Ao comentar o confronto do MPL com a polícia, ela escreve: "Aí reside a violência do movimento: não em vitrines e latas de lixo quebradas, mas no freio brusco da ordem fundada".

\section{Conclusão}

A partir de certa altura dos protestos de junho de 2013, tornou-se frequente que começassem coros de "sem violência", na própria manifestação, diante de qualquer desordem causada por manifestantes. Se me for permitido interpretar esse coro, não é menos que a voz do estado atual da democracia representativa, que diz: não há relação entre direito e violência; o direito que temos é "puro" - como afirma a vulgata de Kelsen -, e toda violência, sendo externa ou contrária ao direito, deve ser rejeitada.

O “direito de manifestação”, assim, enquanto tal, a ser exercido por sujeitos-de-direito estáveis e razoáveis, não pode representar senão uma instância da violência mantenedora do direito, da repetição da violência fundadora do já-posto ou, pelo menos, é uma tipo de violência 
interpretativa que impõe uma leitura (e uma auto-leitura) dos sujeitos nas ruas como apenas cidadãos exercendo seu direito, assim capturando no direito aquela violência que, se devia carregar em si uma ordem diferente da que conhecemos, deveria negar-se a toda explicação em termos interpretáveis a partir do direito vigente.

Procuramos, no curso deste artigo, não apenas desvelar as relações recalcadas entre violência e direito, mas explorar e dissecar essas relações, na medida em que se dão tanto na aplicação e na interpretação do direito, quanto nas práticas que se propõem a transformar ou depor o direito, ou ainda nas tentativas, da parte de comentadores, de interpretar ou "dar voz" ao que se deu nas ruas.

Não tiraremos conclusões sobre as manifestações. Concluir sobre elas seria fechá-las ao seu porvir. Nem gostaríamos dar a elas nomes como "jornadas de junho", "revoltas de junho" ou "primavera brasileira". Sequer desejaríamos ter que decidir entre chamá-las "protestos" ou "manifestações" - não queremos decidir se elas são "contra" ou "a favor" de algo, ou se apenas ocupam fisicamente as ruas. Como concluir, então, se não chamando à manutenção do debate, uma manutenção que, se crítica, deve marcar-se pela contínua ruptura?

O papel do escritor, como costuma dizer Evandro Affonso Ferreira, é o A4. Não há uma função definida porque, nesses momentos, os intelectuais exercem pelo menos duas funções absolutamente necessárias e contraditórias: devem, de um lado, interpretar, representar e calcular, pois a ação prática exige o cálculo; de outro, devem insistentemente questionar toda proposta de interpretação, representação e cálculo, a fim de livrar o evento do conhecimento como violência.

Tudo isso deve ocupar o suficiente nosso papel A4. O resto deve ocupar as ruas.

\section{Referências bibliográficas}

AGAMBEN, Giorgio. Estado de Exceção. São Paulo: Boitempo, 2004.

AVELAR, Idelber. O Enigma de Junho, Parte 1: Os protestos de 2013 e a Amazônia. Disponível em <http://www.idelberavelar.com/archives/2014/04/o_enigma_de_junho_parte_i_os_protestos_ 
de_junho_e_a_amazonia.php>. Acessado em 15/01/2015.

. O Pensamento da Violência em Walter Benjamin e Jacques Derrida. In: Cadernos

Benjaminianos, vol. I, n. 1, junho de 2009. Disponível em:

$<\mathrm{http}$ //Www.letras.ufmg.br/cadernosbenjaminianos/data1/arquivos/02\%20Idelber\%20Avelar. pdf $>$. Acessado em 01/02/2015.

BENJAMIN, Walter. Escritos sobre Mito e Linguagem. São Paulo: Editora 34, 2011.

DERRIDA, Jacques. Força de Lei: O "fundamento místico da autoridade". São Paulo: Martins Fontes, 2007.

. L’écriture et la Différence. Paris: Éditions du Seuil, 1967.

FISH, Stanley. Doing What Comes Naturally: change, rhetoric and the practice of theory in literary and legal studies. Londres: Duke University Press, 1989.

. Is There a Text in this Class? The authority of interpretive communities. Cambridge: Harvard University Press, 1980.

HARVEY, David. A Liberdade da Cidade. In: MARICATO, Ermínia et al. Cidades Rebeldes: Passe Livre e as manifestações que tomaram as ruas do Brasil. São Paulo: Boitempo, 2013, p. 27-34.

MOVIMENTO PASSE LIVRE. Não Começou em Salvador, Não Vai Terminar em São Paulo. In: MARICATO, Ermínia et al. Cidades Rebeldes: Passe Livre e as manifestações que tomaram as ruas do Brasil. São Paulo: Boitempo, 2013, p. 13-18.

PESCHANSKI, João Alexandre. O Transporte Público Gratuito, Uma Utopia Real. In: MARICATO, Ermínia et al. Cidades Rebeldes: Passe Livre e as manifestações que tomaram as ruas do Brasil. São Paulo: Boitempo, 2013, p. 59-64.

ROLNIK, Raquel. Apresentação - As Vozes das Ruas: as revoltas de junho e suas interpretações. In: MARICATO, Ermínia et al. Cidades Rebeldes: Passe Livre e as manifestações que tomaram as ruas do Brasil. São Paulo: Boitempo, 2013, p. 7-12.

SAFATLE, Vladimir. Amar uma Ideia. In: HARVEY, David et al. Occupy: Os movimentos de protesto que tomaram as ruas. São Paulo: Boitempo, 2012, p. 45-55.

SECCO, Lincoln. As Jornadas de Junho. In: MARICATO, Ermínia et al. Cidades Rebeldes: Passe Livre e as manifestações que tomaram as ruas do Brasil. São Paulo: Boitempo, 2013, p. 71-78.

SOREL, Georges. Réflexions sur la violence. Paris: Marcel Rivière et Cie, 1972.

SOUTO MAIOR, Jorge Luiz. A Vez do Direito Social e da Descriminalização dos Movimentos Sociais. In: MARICATO, Ermínia et al. Cidades Rebeldes: Passe Livre e as manifestações que tomaram as ruas do Brasil. São Paulo: Boitempo, 2013, p. 83-88. 
VIANA, Silvia. Será Que Formulamos Mal a Pergunta? In: MARICATO, Ermínia et al.

Cidades Rebeldes: Passe Livre e as manifestações que tomaram as ruas do Brasil. São Paulo: Boitempo, 2013, p. 53-58.

ŽIŽEK, Slavoj. O Violento Silêncio de um Novo Começo. In: HARVEY, David et al.

Occupy: Os movimentos de protesto que tomaram as ruas. São Paulo: Boitempo, 2012, p. 1525.

The Year of Dreaming Dangerously. Londres: Verso, 2012. 